\title{
The Phenomenon of Plica Polonica in Lithuania: A Clash of Religious and Scientific Mentalities
}

\author{
Vaiva Klajumaitè \\ Vilnius University Museum \\ Šv. Jono 12, \\ Vilnius LT-01123, Lithuania \\ E-mail: vaiva.klajumaite@muziejus.vu.It
}

\begin{abstract}
This article focuses on the phenomenon of plica polonica, or Polish plait, known in the baroque and Enlightenment periods in the PolishLithuanian Commonwealth. On the basis of two groups of sources, books of miracles and scientific texts, the article discusses the transformation of the way of thinking. This change is investigated at two levels: first, by identifying the nature of the discourses and their relation to the reality and, second, by analyzing the content of the written sources. This method helps to reveal Polish plait as a representation of a clash of two mentalities, religious and scientific.
\end{abstract}

Keywords: baroque, Enlightenment, discourse, mentality, plica polonica

Polish plait (Lat. plica polonica), a tuft of uncombed and filthy hair, is a phenomenon that existed for a long time in the region of Poland and Lithuania and is often called an affliction exclusively characteristic of this region. Although, chronologically, cases of Polish plait were registered already in the early Middle Ages and even earlier periods, the present paper takes interest in the crucial epoch of baroque and the Enlightenment. This period was noted for an increase in the cases of Polish plait and the emergence of various discourses explaining the causes and treatment of plica polonica. Two groups of sources and discourses of different nature, books of miracles (Lat. liber miraculorum), and texts authored by scholars of medical and other sciences, will be juxtaposed in the paper with an aim to reveal the phenomenon of Polish plait as a representation of a clash of two mentalities, religious and scientific. The author of the current article has tackled this question already in Lithuanian (Klajumaite, 2012), but the phenomenon and the related discourses deserve the attention of a wider scientific audience. 


\section{Thinking and discourse}

First of all, it is important to define, at least briefly, what is considered under 'thinking' and how thinking can be identified with the help of historical sources. One of the basic points is the fact that in the present research we do not consider 'thinking' or 'reason' as a closed and self-sufficient phenomenon. It is rather an individual's conscious relation with the world and its articulation by means of language. In other words, language and thinking are two inseparable things-we could hardly perform an act of thinking without using concepts. This could be confirmed by the ancient Greek word logos signifying both reason and language. A historian analyzing the sources of the past most often has to deal not only with the language as a system of concepts, but also with certain discourses and messages. For a researcher, the latter are both a connecting medium and a puzzle. Representatives of historicism would regard a written source as an intermediary which allows us, with the help of criticism of sources, to probe and explore how everything really happened - that is, get into the historical 'reality'. In the case discussed here the hermeneutic-phenomenological approach, which does not consider the text and its obtuse places as impediments, is more suitable, bearing in mind the fact that a written source is a kind of discourse which by itself creates a new reality. Thus for a historian it makes more sense to analyze how everything is told rather than how it really happened. For that reason, the present research, before analyzing the contents of the sources, shall take into focus the nature of their discourse.

Discourse of books of miracles

As was already mentioned, among the basic sources dealing with the phenomenon of Polish plait are books of miracles. In general, written discourses attesting to miracles are most often divided into three basic groups: miracles registered in the Holy Scripture, the lives of saints (hagiographies), and books of miracles. Graces described in the Holy Scripture are experienced by a small and exclusive group of individuals. In hagiographies, miracles are also related with the life and activity of extraordinary, saintly people, while the contents of the books of miracles most often involve a significantly larger group of individuals. The characters of these sources happen to be of different social class, occupation, and age. According to the Lithuanian art historian Tojana Račiūnaite and the neurologist Vytautas Budrys, liber miraculorum, which began to be formed in the mediaeval times and 
gained spread in the $16^{\text {th }}$ and $17^{\text {th }}$ century, show that miracles acquired a mass character and became more commonplace.

Miraculous healings no longer retain the awesome and majestic halo of the resurrection of St. Lazarus and have become much more earthly and concrete. At the outset realized as extraordinary events pertaining exclusively to very saintly people, miracles become a kind of folk medicine accessible to any believer who has performed an appropriate ritual and offered a votive. (Račiūnaitè \& Budrys, 2007, p. 41)

As a result of the increasing number of experienced miracles, the texts of liber miraculorum were arranged according to a certain structure, which might be called a kind of clericality or "bureaucracy" of miracles: (1) name and surname, occupation and place of residence of the person who experienced a miracle, the course of a disease or the nature of accident; (2) self-devotion or sacrifice of the suffering person; (3) the climax, when the supernatural transformation takes place and the appeal of the devoted person is fulfilled; and (4) an action corresponding to the denouement, when the person who has experienced a miracle comes to church to profess it and offer a votive as a sign of gratitude (Račiūnaite, 2002, p. 224). Though correct, this structural division does not seem to cover the entire topic of the discourse of the books of miracles. Despite the fact that many stories attesting to the experienced graces are quite laconic and similar to each other, they are not typical official documents, distinguished by the shallowness and strict definition of meaning. As we move to the level of phenomenological-hermeneutic research, we can notice more diverse nuances of transparency-obscurity, overlapping of meanings, etc.

Although books of miracles do not belong to the genre of belles-lettres, the thoughts of the German literary scholar Erich Auerbach set out in his work Mimesis (2003) can help reveal the specific character of their discourse. In the first chapter of his book, Auerbach distinguishes between two literary paradigms referring to the relation of the given work to reality. In Auerbach's opinion, Homer's poems Iliad and Odyssey represent the first type. The second type is represented by the stylistics of the Holy Scripture. The author notes that Homer's works are distinguished by precise and detailed representation of the space, time, and characters of the ongoing action. The most important point is

to leave nothing which it mentions half in darkness and unexternalized. The excursus upon the origin of Odysseus' scar [In reference to the scene from The Odyssey, where a maid recognizes Odysseus by a scar on his leg- 
Author's note] is not basically different from the many passages in which a newly introduced character, or even a newly appearing object or implement, though it be in the thick of a battle, is described as to its nature and origin. (Auerbach, 2003, p. 5)

In other words, this discourse makes no claim to truth-it is meant to be admired so that the readers could at least briefly identify themselves with the described plot. According to Auerbach, the exact opposite of this narrative is the biblical discourse, in which

the externalization of only so much of phenomena as is necessary for the purpose of the narrative, all else left in obscurity; the decisive points of narrative alone are emphasized, what lies between is nonexistent; time and space are undefined and call for interpretation; thoughts and feeling remain unexpressed, are only suggested by the science and fragmentary speeches. (Auerbach, 2003, p. 11)

In the Bible, the truth is sought by rejecting an objective relation with the reality.

One could assert that the discourse of books of miracles is similar to the biblical one which contains a great many shadows and obfuscations meant to bring out the action of God. Although liber miraculorum also contains specific details, such as the names and the occupations of concrete persons who experienced a miracle, as well as references to the time and place, these are not the most important details of the text. Much more important is the general motif connecting all narratives - that is the power of God conquering even the most severe diseases, alongside the inexplicability of such a miraculous act. We can as well call this motif a typical expression of religious mentality. As was noted by the philosopher Kurt Wuchterl, the essence of religious thinking or mentality "is both power and impotence. By pointing to the inhibitions of religious statements, this mentality seeks to realize its power, but instead reveals its impotence, as it fails to solve this task." (Wuchterl, 1994, p. 29)

The phenomenon of Polish plait is also involved in this dialectic of power and impotence, as this affliction was considered by many a disease which patients did not respond to treatment and called for an exceptionally miraculous transformation. Any kind of human intervention in an attempt to get rid of the tormenting tuft of hair was shown as detrimental and causing even more complications:

Zofija Mroskowczanka Panna maiąc wielki kołtun na głowie dała go sobie urznąc zkąd potym wielki bol w kosciach y w oczu cierpiała; ta tedy skoro się 
do tego Cudownego obrazu offiarowała zdrową została od wszytkiego bolu.

[Zofija Mroskowczanka, unmarried, cut off a huge Polish plait formed on her head, and for this reason suffered great pain in her bones and eyes. As soon as she devoted herself to a miraculous painting, she was immediately relieved of all her pains.] (Register of the Miracles of Ostrovna, 1655-1658)

Scientists and scholars of the Age of Enlightenment disagreed with this interpretation of plica polonica and tried to change the popular conviction that this affliction was inseparable from a miracle.

\section{Scientific discourse}

Before moving on to the analysis of the contents of medical texts, first of all let us draw attention to the nature of their discourse. Here the above-mentioned literary paradigms, distinguished by Auerbach-Homeric and biblical—should be borne in mind. Books of miracles were closer in the stylistics to the latter because of the abundance of obtuse moments, the manifold character of the text, and their credibility. Strange as it may seem, scientific literature is surprisingly similar to Homer's texts. Authors of both types of texts aim to leave as little obscurity as possible and emphasize and shed light on various details. Readers are constantly compelled to linger on various detailed digressions, which distract them from the basic action. This specific character of medical texts is noted by Jūra Avižienyte in her analysis of the autobiography of Jonas Basanavičius, a Lithuanian physician of the end of the $19^{\text {th }}$ and the beginning of the $20^{\text {th }}$ century:

The abundance of details in Jonas Basanavičius's autobiography irritates and even provokes the reader. Why should he dedicate 330 pages to meticulous lists, quotes, and symptoms of diseases? It almost looks like a physician's notebook or an invoice for the accounting department, and from these pages the reader learns not only with whom Basanavičius maintained contact, what kind of research he made and what he wrote, but also how much he earned, what he ate, what sort of mineral water he drank, and the amount of urate sediments found in his urine. (Avižienytè, 2007, p. 19)

One would expect an inspiring dynamic narrative from the writings of a nation's leader, but instead finds a detailed description of an observation of his and another patient's body. Such a writing style and constant detainment distances 
the reader from the text. A similar process takes place in eighteenth-century scientific literature, in which the opinions of various researchers are discussed at great length and finally refuted, and the research takes another direction. In other words, even without entering into direct polemics with religious explications, the scientific-medical discourse in a certain sense moves away from them. Having found themselves in the scientific field, the phenomena of religious thinking regroup themselves and acquire totally different meanings.

\section{Mentality and classification}

With the aim of bringing out the clash of religious and scientific mentalities, this article shall employ yet another concept-classification. It is a universal property of the mind which cannot be strictly attributed to either of the mentality types. Nevertheless, the principles and starting points of classifications can be quite different.

Classification in religious mentality and the devaluation of the symbolism of Polish plait

Alongside the horizontal classification of the beings of the horizontal world, one of the basic distinctions in religious mentality is the sacrum-profanum scale, which gives added value to various objects and makes them part of an order that is difficult to change. According to the French sociologist Emil Durkheim:

In all the history of human thought there exists no other example of two categories of things so profoundly differentiated or so radically opposed to one another. The traditional opposition of good and bad is nothing beside this; for the good and the bad are only two opposed species of the same class, namely morals, just as sickness and health are two different aspects of the same order of facts, life, while the sacred and the profane have always and everywhere been conceived by the human mind as two distinct classes, as two worlds between which there is nothing in common. (Durkheim, 1915, p. 38)

While analyzing the experiences of the sacrum-profanum distinction and its articulation in various cultures, religious phenomenologists (e.g., Rudolf Otto 
and Mircea Elia) emphasize that there is no void or empty space in between these categories, but rather they are connected through a symbolic relation: the natural world represents and embodies sacrality, and sacrum must be articulated through the profane. Both the primary and the secondary meanings cannot be distinguished and separated from one another.

In books of miracles, the phenomenon of Polish plait under discussion is also regarded as a symbolic expression of sacrality, a hierophany directing us beyond itself. However, the interpretation of Polish plait as a symbol also reveals the crisis of signification of otherness itself. In the words of Račiunaitè and Budrys (2007, p. 43), "[s] ociety was dominated by a conviction that Polish plait was a punishment from God, 'a substance of disease', which could not be simply disposed of by cutting off one's hair, as it incurred serious complications". Calling plica polonica a material manifestation of a disease or evil eliminates the secret of a symbol and turns it into an obvious, visible, material object. This act of explication is performed at the expense of devaluation and exposure of symbolism. Incidentally, this process started by the religious discourse was continued and consolidated in scientific research.

Polish plait in the systems of cognition of Diderot and Bisio

One of the most influential publications of the Age of Enlightenment to include Polish plait in its field of attention was Diderot's encyclopaedia (Encyclopédie, ou dictionnaire raisonné des sciences, des arts et des metiérs; Diderot \& D'Alembert, 1751). Although some publications of encyclopaedic nature had appeared earlier, this project was distinguished by its scale and the elevation of science as power. According to Robert Darnton, the author of a collection of essays The Great Cat Massacre and Other Episodes in French Cultural History (1985), "[i]nstead of showing how disciplines could be shifted within an established pattern, it [Diderot's encyclopaedia-Author's note] expressed an attempt to raise a boundary between the known and the unknowable in such a way as to eliminate most of what men held to be sacred from the world of learning" (Darnton, 1985, p. 194). This publication from the Age of Enlightenment, which built its own classificatory system, leaves no room for the layer of sacrum. Any phenomenon or object of the world had to be explored within the limits of human cognition or not explored at all. Any speculations were rejected as ignorant and even disastrous. 
In the encyclopaedia, plica polonica is included under the section of pathologies, the subgroup of medicine, and the group of natural sciences (Darnton, 1985, p. 211). In other words, having been regarded as a manifestation of sacrality, Polish plait is transferred to the layer of anomalies, and the author of the encyclopaedic entry obviously takes a polemic position against the religious and all the other discourses:

Quelques-uns ont accusé des causes plus ridicules, chimériques, que la crainte enfante, que l'attrait frivole $\&$ puissant du merveilleux accrédite, \& que l'ignorante crédulité soutient. Un vulgaire insensé qui est de tous les pays a cru, \& des auteurs encore plus sots, parce qu'étant éclairés ils devoient l'être moins, ont écrit; ceux-ci, que le plica devoit son origine à des enchantemens, des opérations magiques, \& qu'il ne pouvoit être dissipé que par des secours surnaturels ; ceux-là, que l'entrelacement des cheveux étoit l'ouvrage des enfans morts, non baptisés, qui venoient travailler à cela pendant la nuit ; \& pour perpétuer cette sottise, on a donné au plica le nom allemand de wichtel zoepffe; wichteln signifie dans l'ancien langage non baptisé, \& zoepffe, noeud, entrelacement. Les uns, que c'étoit des incubes qui venoient sucer $\&$ nouer ainsi les cheveux ; les autres, que ces incubes paroissoient sous la forme d'une femme juive, \& cette erreur populaire est encore marquée dans ce nom, juden-zoepffe, \&c. \&c.

[Some authors emphasized even funnier fantastic causes, which were enlarged by fear, spread by deep-seated foolish faith in miracles, and maintained by ignorant credulity. Some common ignoramus, any number of whom can be found in all countries, believed it, and some even more stupid authors wrote about it, although being educated, they should know better than that; according to these authors, Polish plait is caused by magic, magical actions, and can be healed exclusively by supernatural means. According to other authors, the entanglement of hair is brought upon by dead unbaptized infants who perform this work at night. This nonsense was perpetuated by giving it a German name wichteln zoepffe; in Old German wichteln means 'heathen', and zoepffe- 'knot', 'entanglement'. Some authors write that only incubi come to suck upon and entangle hair; others argue that incubi appear in the shape of a Jewess, and this popular delusion is registered by the name of juden-zoepffe, etc.] (Diderot, 1751, pp. 767-768)

However, despite severe criticism, the ingenious explanation of Polish plait also prompted interest in this phenomenon. Strange symptoms of this disease manifesting themselves in transformations of hair colour and structure, as well 
as a great many fears surrounding this ailment turned the subject of Polish plait into a fashionable topic of salon conversations or even an exhibition of the Kunstkammer. In other words, plica polonica became an exotic oddity arousing interest, and was compared to bizarre plants of various countries, masks brought from the African continent, or details of clothing of the Far East. Having found itself in the contents of scientific discourse, Polish plait became a curious exhibit whose symbolic character is completely devalued.

Scientists of the Polish-Lithuanian Commonwealth also reacted to this widespread phenomenon in their country. Two decades after Diderot's encyclopaedia came out, Stefan Bisio, a physician of Italian descent and a lecturer of medical subjects at the Vilnius University, published a booklet titled A Reply of the Doctor of Philosophy and Medicine Stefan Bisio to the Question from the Philosophical Society About Melancholia, Mania and Polish Plait (Responsum Stephani Bisii Philosophiae et Medicinae Doctoris ad Amicum Philosophum De melancholia, mania et plicapolonica sciscitantem; Bisio, 1772). The title indicates that the booklet was written in the form of correspondence. The pre-publication history seems to be quite obvious: having taken interest in the diseases of melancholia, mania, and Polish plait, members of the Philosophical Society asked Bisio, a respectable lecturer of the Vilnius Jesuit University, for an explanation. However, at the same time all these circumstances are intriguing and pose quite many questions: why should philosophers be interested in medical issues, why are these three particular diseases treated together, and why did the doctor's reply end up becoming a printed publication?

The answer to the last question is quite simple: the publication of the printed text (unfortunately, the number of copies is not known) shows an aim to reach a wider audience. This would also be confirmed by the fact that the publication is bilingual, written in Latin and Polish. One could think that Bisio struggles against certain inveterate and, in his opinion, ungrounded views and thus initiates a new discourse and seeks to spread it.

Bisio's work starts with polite introductory sentences, but very soon he moves on to specific definitions of melancholia and mania. According to the author,

Melancholia is confusion of the mind (pomieszanie rozumu) without fever, rising from fear, sadness, and constant preoccupation, in which fantasy (imagining of objects) becomes extremely distorted. Mania is confusion of the mind without fever along with rage, reckless courage, and great strength. (Bisio, 1772, p. 2) 
These primary descriptions of the diseases become a point of reference for Bisio to move on to the problematic part of the subject. As it turns out, the physician is irritated by speculations surrounding the topic of melancholia and mania by various thinkers who describe mental weakness as a result of discord between the spirit and the body. The author criticizes all attempts at associating medicine with metaphysical speculations (which the Philosophical Society most probably expected by asking the physician this question). Finally, the apologetic is ended with a polite but strict statement, "[i]t would be great foolishness to attribute the causes of stupidity to a flaw of the spirit. Proceeding from this basis, I am going to talk briefly about melancholia and mania in a plain language understandable to everyone." (Bisio, 1772, p. 4) The fact that the physician distances himself from mental weakness and limits himself strictly to the physiological aspect is a peculiar response and alternative not only to the philosophers' thoughts, but also to the religious discourse and mentality of the time. He seeks to reject any symbolic character of anomaly once and for all, and explain strange symptoms regardless of the causes and complexity of the disease.

Although Bisio considered Polish plait a somewhat different case than the diseases discussed at the beginning of his work, his programme is similar: to distance himself from any explanations relating it to human or any other kind of spirit. The physician's reasoning could be called the demythologization of Polish plait as it dissipates the deep-seated superstitions and fears related with plica polonica. In general, according to Bisio, myths are widespread not only among ordinary people, but also among acclaimed physicians, none of whom dared to confirm the statement that Polish plait was not a disease, but a projection of other ailments into a tuft of entangled hair resulting from a slovenly life. Referring to the examples from his long-term medical practice, the author announces a ruthless verdict: Polish plait is not a disease, but a tall tale of various charlatans, old ladies from the village, and priests (Bisio, 1772, p. 34).

\section{The overlapping of religious and scientific mentalities?}

Finally we shall discuss the continuation of polemics initiated by Bisio. Interestingly enough, a negative reaction rose not among the clergy, but among his physician colleagues. It is testified by a decree that the Bishop of Vilnius Ignotas Jokūbas Masalskis proclaimed in Warsaw in 1773 and opens with an address "To all and every inhabitant of my bishopric" (Masalski, 1773). The 
decree expresses indignation at the newly published polemical publication directed against Bisio's methods of treatment:

Quum nihil, praeter animam, praestantius habeat homo, quam amissae valetudinis, recuperationem, ideo curavimus, ut rationalis Medicus inhabitatorum commodo, Vilnensem incoleret Civitatem ; in quem honestum, \& rationalem Medicum, nobisque diu bene notum, legitimis Philosophiae, \& Medicinae laureae Diplomatibus decoratum, pliuriumque Celeberrimarum Italiae Academiarum approbationibus munitum, uti Episcopali Nostrae constat Curiae, libellus famosus (cui est titulus De perversa medendi Methodo \& c. sub die 13. Maji 1773. posthabitis Superiorum facultatibus a quocumque Typhographo ubique servandis. Vilnae, ut praesumitur, impressus) a quatuor hebdomadibus summa admiratione $\&$ indignatione nostris legendus subjiciebatur oculis. Non semel equidem Lithvana nostra Metropolis Doctum virum \& in arte Medica clarum, individorum $\&$ ignorantum obtrectationes vexationesque pertaesum, doluit in tuta a nobis recedentem!

[As there is nothing more important for an individual, except perhaps for his soul, than to regain the lost health, we made sure that a qualified physician came to live in the city of Vilnius for the convenience of its residents, and a scandalous booklet titled "On an Inappropriate Method of Treatment, etc." published on 13 May 1773 supposedly in Vilnius despite the prohibition of the superiors, which should be observed by any printer anywhere, [directed] against this respectable and qualified physician (rationalis Medicus), whom we have known for a long time, and who has valid diplomas in philosophy and medicine and is acclaimed by many outstanding Italian academies to the knowledge of the curia of our bishopric, was brought for us to read four weeks ago to our great amazement and indignation. Our Lithuanian capital has regretted not once that this learned person renowned for his ability to treat diseases is leaving to a quieter place, as he has had enough of the enmity and attacks of the envious and the ignorant.] (Masalski, 1773)

The bishop's letter is symptomatic as well. The hierarch of the Catholic Church sides with the rationalis Medicus, and calls any opinions contradicting him incongruous "with the virtuous and Christian faith" (Masalski, 1773). The fear of the spread of pseudo-sciences, charlatans, and superstitions prompted changes in the religious environment itself, which had taken the way of merging with the secular discourse. In the Polish-Lithuanian Commonwealth this merging took place not so much through an undermining of the influence of the Catholic 
Church, but by building "Catholic Enlightenment". In the words of Lithuanian historian Eligijus Raila,

[b]y gradually ousting out the traditional means of treatment, the empirical medical thought of the period of Enlightenment offered a qualitatively new logic of struggle against diseases, epidemics, and death, whose final outcome was considered by the Church as the harmony of body and soul. On the other hand, the integral development of the body prompted by the influence of philanthropy testified to a new system of anthropological views. (Raila, 2010, p. 153)

As one can see from this quotation, the relation of the Church with natural sciences was rather contradictory. On the one hand, this kind of dialogue was a condition for the survival of the Catholic community, but on the other, a process that could be called the oblivion of sacrality was taking place. The religious and scientific modes of thinking cannot be put into direct opposition, but their synchronization is hardly possible.

The polemics surrounding Polish plait continued throughout the $19^{\text {th }}$ century. Many local and visiting physicians-Bernard Jan Alex, Adam Adamowicz, Joseph Frank, August Bécu and others-took interest in the phenomenon of plica polonica. Several records about the organizing of special competitions for the research of Polish plait have been preserved (Adamowicz, 1865; 1869; About the article..., 1859; About the competition..., 1858-1859). However, further discussion of physicians took place on a secular professional level: the question whether plica polonica was a disease was constantly asked, and if so, what caused it and how it could be treated. For example, a well-respected physician Joseph Frank, who lived in Vilnius in the early $19^{\text {th }}$ century, mentions in his diary that Polish plait could be related to cancer (Frankas, 2001, p. 232), and unlike Stefan Bisio, strictly forbade cutting off the tormenting tangle of hair (Frankas, 2001, p. 458).

However, the physicians' interest and discussions, apart from bringing to light some new aspects, did not cause more serious upheavals. A new generation of scholars continued the research in pathology, and religious discourses explaining Polish plait sunk to the margins of Lithuanian culture. 


\section{Conclusion}

The article suggests that the different types of sources, religious and scientific, do not contrast with each other only because of their content. These texts implicate different ways of thinking and attitudes to the same object—in our case, Polish plait. Unlike books of miracles, in which the juxtaposition of human ailment and the power of God, as well as the symbolism of disease prevailed, scientific discourses are noted for quite a different way of mentality. Their trajectory moves to the horizontal level, which consists of the areas of cognition and yet non-cognition. Furthermore, we can see that the research of the early medical scientists is strongly connected with religious discourses. The standpoints of the authors of the scientific publications are counteractive, meaning that they define their identity through polemics with the field of religion and this way perform a distinct shift in thinking. This shift is not a replacement of one classificatory system with another, but a transformation of the point of departure of thinking itself.

\section{References}

About the article which was sent to Paris (1859), [Unpublished manuscript] VUL inv 26 f 4811, Vilnius: Vilnius University Library.

About the competition on the researches of polish plait (1858-1859), [Unpublished manuscript] VUL inv $26 \mathrm{f}$ 4810, Vilnius: Vilnius University Library.

Adamowicz, A. (1865), Myśli niektòre o kottunie [Some thoughts about Polish plait], [Unpublished manuscript] VUL inv 26 f 4820, Vilnius: Vilnius University Library. - (1869), Kilka stow pobieźnych do historyi kołtunu i rozbior teoryi Franka [Several superficial considerations about the history of Polish plait and Frank's Theory], [Unpublished manuscript] VUL inv 26 f 4826, Vilnius: Vilnius University Library.

Auerbach, E. (2003), Mimesis: The Representation of Reality in Western Literature, Princeton: Princeton University Press.

Avižienyte, J. (2007), 'Ligos retorika: nacionalizmas ir isterija Jono Basanavičiaus autobiografijoje' [The rhetoric of diseases: nationalism and hysteria in Jonas Basanavičius's autobiography], Baltos lankos, no. 14, pp. 17-34.

Bisio, S. (1772), Responsum Stephani Bisii Philosophiae et Medicinae Doctoris ad Amicum Philosophum De melancholia, mania et plica-polonica sciscitantem, Vilnius: s.n.

Darnton, R. (1985), The Great Cat Massacre: And Other Episodes in French Cultural History, New York: Vintage Books. 
Diderot, D. \& D’Alembert, J. R., eds. (1751), 'Plica Polonica,' in Encyclopedie, ou Dictionnaire raisonné des sciences, des arts et des metiérs, Paris, vol. 12, pp. 767-768. Retrieved from: http://artflsrv02.uchicago.edu/cgi-bin/extras/encpageturn.pl?V12/ ENC_12-767.jpeg [accessed 23 Aug 2013]

Durkheim, E. (1915), The Elemetary Forms of the Religious Life, London: George Allen \& Unwin Ltd.

Frankas, J. (2001), Atsiminimai apie Vilniu [Memories of Vilnius], Vilnius: Mintis.

Klajumaitè, V. (2012), 'Kaltūno fenomenas šventybès anomalejimo perspektyvoje' [The phenomenon of Polish plait from the perspective of sacrality], Naujasis ŽidinysAidai, no. 1, pp. 41-45.

Masalski, I. (1773), 'To all and every inhabitant of my bishopric Warsaw,' VUL inv Med. dr. f 531, Vilnius: Vilnius University Library.

Račiūnaitė, T. (2002), 'Lukiškių Šv. Jokūbo ir Pilypo bažnyčios Dievo motinos paveikslas ir jo stebuklų knyga 'Mistinis fontanas...'. Stebuklo vieta ir laukas' [The picture of the Mother of God in the Church of St. James and St. Philip and The Mystery Fountain book of miracles], Acta Academia Artium Vilnensis, no. 25, pp. 223-240.

Račiūnaitė, T. \& Budrys, V. (2007), 'Stebuklų laukas ir neurologija: neurologiniai sutrikimai Lietuvos stebuklų knygose' [Magic and neurology: neurological disorders in Lithuanian books of miracle], Neurologijos seminarai, vol. 11, no. 31, pp. 39-46. Retrieved from http://www.neuroseminarai.lt/lt/2007-m-nr-131/ [accessed 23 Aug 2013]

Raila, E. (2010), Ignotus Ignotas, Vilnius: Aidai.

Register of the Miracles in Ostrovna (1655-1658), [Unpublished manuscript], VUL inv 4 f 342, Vilnius: Vilnius University Library.

Wuchterl, K. (1994), Religinis protas. Analize ir kritika [Religious mind: analysis and criticism], Vilnius: Taura.

Vaiva Klajumaitè was born in Vilnius and received her bachelor's degree in Cultural History and Anthropology from the Vilnius University (2009). In 2011, she graduated with MA in Religion from the Vilnius University. Vaiva Klajumaite currently works at the Vilnius University Museum and conducts research in cultural history, cultural philosophy and the related disciplines. 